\title{
Wide-range dispersal in juvenile Eagle Owls (Bubo bubo) across the European Alps calls for transnational conservation programmes
}

\author{
Adrian Aebischer $\cdot$ Peter Nyffeler $\cdot$ Raphaël Arlettaz
}

Received: 23 August 2008/Revised: 24 April 2009/Accepted: 27 April 2009/Published online: 18 May 2009

(C) Dt. Ornithologen-Gesellschaft e.V. 2009

\begin{abstract}
Although juvenile dispersal is an important life history component, it remains one of the less understood ecological processes regulating the dynamics of animal populations. Lack of information about patterns of dispersal hampers the estimation of the actual status and demographic trajectory of populations, and can preclude the development of sound conservation strategies. The Eagle Owl Bubo bubo is an endangered bird species in the European Alps. Many breeding sites have been abandoned in the twentieth century, although some recovery has been reported lately. Moreover, the occupancy of traditional breeding sites across years in well-monitored Alpine populations varies a lot, this despite a relatively high breeding success at the population level. This raises concern about the long-term persistence of Alpine populations. Using conventional and satellite radiotracking, we investigated the spatio-temporal dispersal of 41 juvenile Eagle Owls originating from a population in the southwestern Swiss Alps. Our main goal was to determine dispersal distances, places and times of post-dispersal settlement. Juveniles left their parents between mid-August and mid-November.
\end{abstract}

Communicated by F. Bairlein.

A. Aebischer $(\bowtie) \cdot$ P. Nyffeler · R. Arlettaz Division of Conservation Biology, Institute of Ecology and Evolution, University of Bern, Baltzerstrasse 6, 3012 Bern, Switzerland

e-mail: adaebischer@pwnet.ch

R. Arlettaz

Swiss Ornithological Institute, Valais Field Station,

Nature Centre, 3970 Salgesch, Switzerland

R. Arlettaz

The Ecology Centre, University of Queensland,

St Lucia, QLD 4072, Australia
They covered, on average, $12.7 \mathrm{~km}$ per night (linear distance between two consecutive day roosts), often crossing high mountain ranges (up to 3,000 m altitude). The mean total distance covered by an individual during dispersal was $102 \mathrm{~km}$ (sum of night movements), with a maximum of $230 \mathrm{~km}$. Settlement places were, on average, $46 \mathrm{~km}$ distant from the birth place. Our study establishes longdistance dispersal in juvenile Eagle Owls, even in a complex topography, suggesting the existence of a wide-scale metapopulation system across the northwestern Alps. This metapopulation dimension should be accounted for in conservation plans.

Keywords Alps $\cdot$ Bubo bubo · Floater . Juvenile dispersal $\cdot$ Satellite telemetry

\section{Introduction}

Although dispersal is a crucial life history component of most organisms' biology, it remains one of the less understood ecological processes regulating the dynamics of animal populations (Clobert et al. 2001). Commonly, conventional population dynamic models fail to distinguish between local mortality and permanent emigration (Burnham 1993), which affects the predictive power of population viability analyses. Most models make too simplistic assumptions as regards dispersal (overview in Bowler and Benton 2005). The recognition of the patterns of dispersal, emigration and immigration is thus essential for estimating population demographic status and trajectory, so as to launch sound conservation action plans. Penteriani et al. (2006) have shown that, when the existence of a substantial population of floaters (individuals ready to settle in vacant territories) is necessary for ensuring a stable 
demographic turnover, ignoring the fate of the floating segment of a population might lead to erroneous expectations regarding demographic trajectories. It has therefore been suggested that the destiny of floaters has to be investigated before judging of the good health of a population based solely on the number of breeding pairs and their seemingly sufficient productivity (Delgado and Penteriani 2005).

A typical example is the Eagle Owl Bubo bubo, a threatened nocturnal raptor in European ecosystems. This species is affected by a huge anthropogenic mortality, due in particular to electrocution and collision with trains and vehicles (Rubolini et al. 2001; Marchesi et al. 2002; Aebischer et al. 2005; Valkama and Saurola 2005; Breuer 2007, 2009). A large reservoir of floaters might in this species be essential for compensating for the losses caused by anthropogenic factors. The high spatio-temporal variation observed in breeding site occupancy in Eagle Owls (Defontaines 2002; Sergio et al. 2004) may reflect a certain chaos generated by additive mortality in the absence of replacement individuals within a population's basin. Indeed, many breeding sites have been abandoned in recent years in the Alps, or were occupied only irregularly despite a relatively high breeding success (e.g. Aebischer et al. 2005). In order to actually understand the population dynamics of Eagle Owls in the Alps, the fate of dispersing individuals and the area of settlement of dispersers needs to be determined beforehand. Using conventional and satellite radiotracking, we investigated the spatio-temporal dispersal of juvenile Eagle Owls originating from a lowdensity, endangered Alpine population which has been monitored since the late 1980s in the canton of Valais (southwestern Swiss Alps) and the adjacent areas (Arlettaz 1988; Mosimann-Kampe et al. 1998). The main goal of this paper is to present data on dispersal distances, places and times of settlement of juveniles.

\section{Methods}

Between 2002 and 2006, 41 Eagle Owl nestlings were tagged in Valais and adjacent areas $\left(46.1^{\circ} \mathrm{N}-46.4^{\circ} \mathrm{N}\right.$, $\left.6.8^{\circ} \mathrm{E}-8.9^{\circ} \mathrm{E}\right)$. Valais consists of a long, deep valley enclosed by high mountain ranges on each side except the northwest close to the Lake of Geneva; it is the most upstream segment of the Rhône valley. The young Eagle Owls stemmed from 23 different broods reared at 10 different sites which were located between 300 and $1,850 \mathrm{~m}$ altitude. However, 40 young were born below $850 \mathrm{~m}$ altitude, with only one young marked in an eyrie at $1,850 \mathrm{~m}$. The birds were captured between mid-May and early July, at the age of 5-7 weeks, while still in the nest. The age was determined following Scherzinger (1974) and Penteriani et al. (2005). We equipped 21 out of 41 young Eagle Owls with 30-g battery-powered satellite transmitters supplied by North Star Science and Technology (King George, VA, USA). Small VHF tags (Model RI-2CP, 6 g, life span 12 months; Holohil System, Ontario, Canada) were attached to the satellite transmitters in order to track and retrieve the birds in the field. The remaining 20 young were fitted just with 15-g VHF tags (Model RI-2CP, life span 32 months; Holohil System). All tags were attached as backpacks using Teflon ribbon (Bally Ribbon Mills, Bally, PA, USA) as a harness. The tag packs represented in all cases less than $2.2 \%$ of the minimum body mass observed in adult Eagle Owls in Central Europe (1,700 g; Glutz von Blotzheim and Bauer 1980; own data). Immediately after tag installation, birds were released into the nest. All satellite tags included an activity sensor (a mercury switch that increments a counter each time the switch is opened or closed) that allowed us to infer tag movement between two consecutive signals. In most conditions, this indicated whether a bird was still alive. Likewise, the radio pulse rate of the VHF tags in a horizontal position was twice as high as the signal pulse rate in a vertical position. Four of the 21 satellite tags were set to a constant duty cycle of $8 / 36 \mathrm{~h}$ (on/off, respectively). The other satellite transmitters were programmed with three different duty cycles: 8/105 h on/off during the first initial 3 months, then $8 / 37 \mathrm{~h}$ during 4 months and, finally, $8 / 97 \mathrm{~h}$ on/off for the rest of the battery life. For 12 satellite tags, the battery lasted, on average, 7.25 months (range 6.5-8.5). The other nine tagged birds all died before the battery was exhausted. All satellite tags were programmed for a signal repetition period of $45 \mathrm{~s}$. The signals of the transmitters were recorded by the ARGOS satellite system (www.cls.fr). Each localisation calculated by ARGOS is provided with a measure of position accuracy, given in six precision classes. According to ARGOS, the location errors of the three best classes (called LC3, LC2, LC1) follow a normal distribution with a standard deviation being less than $1,000 \mathrm{~m}$. For the remaining three precision classes (called LC0, LCA and LCB), also delivered by ARGOS, no accuracy is specified by the company, but Hays et al. (2001) and Vincent et al. (2002) reported that LCA locations are of a similar accuracy as LC1 locations. In contrast, LC0 and LCB have much lower localisation accuracies. We thus used the latter two only if two subsequent localisations fell within a radius of less than $5 \mathrm{~km}$.

In order to establish either local (i.e. nest surroundings) mortality or the date when juveniles left their birth site, non-fledged tagged nestlings were controlled twice a week in the field. Once fledged, juveniles were controlled every other day until they quit the birth site. Birds bearing a VHF tag were then tracked every night, with just a few exceptions. Birds with a satellite tag were searched for in the field only when we suspected that they might have died (no 
localisation during an «on-period» of the transmitter or constant values from the activity sensor for more than $12 \mathrm{~h}$ in a row). However, due to the low spatial resolution of ARGOS, and relatively long time lapse between two subsequent ARGOS localisations, distances flown by young and altitude of crossed passes were not estimated with this dataset. Only data collected with VHF tags were used to that end.

In our definition, the first phase of juvenile dispersal corresponds to the time period from the date a young left its parents to the first place where it stayed for at least 1 month. Indeed, most of the young moved quite a lot for several weeks before they became suddenly sedentary, in autumn.

The total distance travelled during the first phase of juvenile dispersal was calculated by summing up the night distances covered by the birds, i.e. the distances between two subsequent day roosts. Only those young that were tracked every night were used for that purpose $(n=13)$. The linear distance between birthplace and settlement site is hereafter called settlement distance, while the maximum dispersal distance is the distance between nest and the furthest location ever reached. In order to find out whether the young preferred a special direction when dispersing, bearings of the main flight direction were taken for each individual after 2 days, 1 and 2 weeks, as well as at the end of the first dispersal phase. We used the Rayleigh test to test for preferences for a given direction (Batschelet 1981). Averages are given \pm 1 standard deviation.

\section{Results}

Onset and age of dispersal

The first young hatched on 22 March, the last one on 23 May (median: 17 April, $n=41$; Table 1). All tagged nestlings survived up to the age of 2 months when they became able to fly. Forty out of 41 young always stayed closer than $500 \mathrm{~m}$ to the nest before starting dispersal. Only one bird that was still fed by the parents was localised several times at 1,200 $\mathrm{m}$ from the nest. Twelve out of 41 young (29\%) died between 9 and 28 weeks of age (average $16.3 \pm$ 5.5 weeks) before they could start dispersal. The remaining 29 birds left their parents between 13 August and 20 November (median: 30 September), but 5 of these 29 young (17\%) dispersed only in November. The onset of dispersal occurred at a median age of 23 weeks, ranging from $20.5 \mathrm{~s}$ to 29 weeks. The earlier in the season a young hatched, the earlier it dispersed (Spearman rank correlation: $r_{\mathrm{s}}=0.787$, $p<0.0001)$. Eagle Owls that left their parents earlier in the season were also younger than juveniles that dispersed later (Spearman rank correlation: $r_{\mathrm{s}}=0.595, p<0.01$ ). The 13 Eagle Owls that left the breeding area and for which the exact date of death is known passed away at an age between 5.5 and 34 months (average: $10.5 \pm 8.6$ months). Five more individuals survived at least until the battery of their tag was exhausted, i.e. reached a minimum age of 11-24 months (15.4 \pm 4.6 months).

\section{Duration and distances of dispersal}

The first phase of juvenile dispersal lasted 3-90 days (average: $29.8 \pm 24.8$ days, $n=16$ birds). The first Eagle Owls arrived at settlement places on 6 September, the last ones on 10 December (median: 27 October).

The mean night distance per bird was $12.2 \pm 5.8 \mathrm{~km}$ (range: $4-28 \mathrm{~km}, n=15$ birds). From 68 documented night movements, $34(50 \%)$ were shorter than $10 \mathrm{~km}$ and 5 (7\%) larger than $30 \mathrm{~km}$, with a maximum of $34 \mathrm{~km}$ ( $n=15$ birds). Only 2 out of 15 birds (13\%) travelled at least once more than $30 \mathrm{~km}$ during a single night.

The dispersal distance from the native place of course increased with time (Fig. 1). After 1 week, young were, on average, $26.2 \pm 19.7 \mathrm{~km}$ away from the nest $(n=26)$, and after 2 weeks $36.5 \pm 25.2 \mathrm{~km}(n=26)$.

The total distance (sum of night distances) covered by the birds which were tracked precisely during dispersal was, on average, $102 \pm 66 \mathrm{~km}$ (range: $20-230 \mathrm{~km}, n=13$ birds). For nine birds with incomplete tracking (loss of radio signal), the minimal total dispersal distance was at

Table 1 Some features of the dispersal process in radiotagged juvenile Eagle Owls Bubo bubo

\begin{tabular}{|c|c|c|c|c|c|c|c|}
\hline & $\begin{array}{l}\text { Hatching } \\
\text { date }\end{array}$ & $\begin{array}{l}\text { Date when } \\
\text { juvenile owls } \\
\text { left their } \\
\text { parents }\end{array}$ & $\begin{array}{l}\text { Duration of the } \\
\text { first phase of } \\
\text { dispersal (days) }\end{array}$ & $\begin{array}{l}\text { Total } \\
\text { distance } \\
\text { covered } \\
(\mathrm{km})\end{array}$ & $\begin{array}{l}\text { Average } \\
\text { distance } \\
\text { covered per } \\
\text { night }(\mathrm{km})\end{array}$ & $\begin{array}{l}\text { Maximum distance from } \\
\text { the nest during the first } \\
\text { phase of dispersal }(\mathrm{km})\end{array}$ & $\begin{array}{l}\text { Distance from the nest at } \\
\text { the end of the first phase } \\
\text { of dispersal }{ }^{\mathrm{a}}(\mathrm{km})\end{array}$ \\
\hline Min & $22 \mathrm{Mar}$ & 13 Aug & 3 & 20 & 4 & 12 & 3 \\
\hline Max & 23 May & $20 \mathrm{Nov}$ & 90 & 230 & 28 & 105 & 95 \\
\hline Mean & $14 \mathrm{Apr}$ & 3 Oct & 29.8 & 102 & 12.2 & 57.8 & 46.1 \\
\hline Median & 17 Apr & $30 \mathrm{Sep}$ & 20 & 105 & 12 & 56 & 43 \\
\hline$n$ & 41 & 29 & 16 & 13 & 15 & 28 & 18 \\
\hline
\end{tabular}

${ }^{a}$ The end of the first phase of dispersal is here defined as the time when a young arrived at the place where it stayed for at least 1 month 


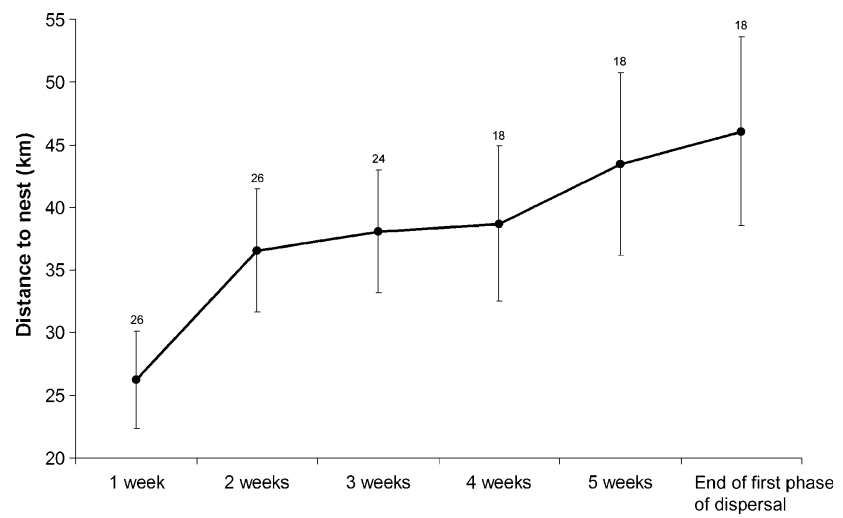

Fig. 1 Progressive distancing from the nest in dispersing juvenile Eagle Owls Bubo bubo. Means $( \pm \mathrm{SE})$ after different time periods are shown. Numbers indicate sample sizes

least $150 \mathrm{~km}$. These birds all went to regions in France or Italy, i.e. farther away than most of the other individuals. In addition, a bird that was found enfeebled on 14 November 2006, 34 days after the start of dispersal, then nourished at a rescue centre and released on 6 January 2007, 53 days after its rescue, at the same place, flew a total distance of at least $480 \mathrm{~km}(180 \mathrm{~km}$ before it was found and $300 \mathrm{~km}$ after its release). Its tag battery went exhausted when the bird was $120 \mathrm{~km}$ from its birth place, which also represents the longest settlement distance.

The maximum dispersal distance (distance between the nest and the furthermost roosting place that we were able to record) was, on average, $57.8 \pm 27.7 \mathrm{~km}(12-105 \mathrm{~km}$, $n=28$ birds).

The average settlement distance was $46.1 \pm 31.9 \mathrm{~km}$ (range: 3-95 km, $n=18$ ) (Table 1). This distance did not correlate with the age of the young at dispersal start (Spearman rank correlation: $r_{\mathrm{s}}=-0.33, p=0.18$, $n=16)$ nor with the date when the young left parents ( $r_{\mathrm{s}}=0.14, p=0.60, n=16$ ). In 10 out of 18 young $(56 \%)$, the settlement distance was shorter than the maximum distance from the nest flown during dispersal. In three individuals, a progressive return towards the proximity of the native place could be observed. Our young Eagle Owls that were born in the Rhône valley in an area of about $1,020 \mathrm{~km}^{2}$ (minimum convex polygon including all nests) spread out to an area of about $21,550 \mathrm{~km}^{2}$ (minimum convex polygon encompassing all external settling locations or sites where individuals died).

Dispersal directions, topographic barriers

and wintering grounds

All birds spent the whole winter in the initial settlement site. Eight birds left this initial area, on average, $3.7 \pm 3.1$ months later (range: 50 days to 11 months). Six other birds stayed in the initial area until they died or until
Fig. 2 Maps showing the itineraries chosen by young dispersing Eagle Owls born in the southwestern Swiss Alps. The dots indicate nesting sites, the black crosses specify birds that died, the stars show mountain tops and the squares represent small towns. The itineraries are spread on three different maps for reasons of clarity

the tag battery was exhausted, i.e. for 3.5-10 months. All in all, 9 out of 14 birds (64\%) stayed for at least 3.5 months in the initial settlement area.

From 24 Eagle Owls that were born in Valais (Fig. 2), only 8 settled in Valais; 5 went to Italy, 5 to France, and 6 to the cantons of Bern and Fribourg (north of the Alps). The young never travelled during daytime; all flying activities were recorded between sunset and sunrise. They initially followed the axes of the principal valley and main tributaries, but most of them eventually crossed mountain passes and/or ridges. Only 10 out of 28 birds never crossed any mountain ridge. Fifteen individuals overflew passes higher than 2,000 $\mathrm{m}$ a.s.l., with seven birds crossing passes higher than 2,800 m elevation and two birds even crossing ridges above $3,000 \mathrm{~m}$. Two-thirds of all dispersing individuals stayed for at least 3 days in a row at altitudes above $1,000 \mathrm{~m}$ a.s.1.

Two days after the onset of dispersal, 13 out of 26 birds were located north or north-east of the nest site (Fig. 3), establishing a dispersal differing from a purely random pattern (Rayleigh test: $z=9.35, n=27, p<0.001$ ). There was then a switch towards north-east (after 1 week) and finally south-west (after 2 weeks and at the end of the first phase of dispersal; Fig. 3). Eight out of 28 young (29\%) started dispersal toward high mountains, while the remaining 20 birds first followed major valley axes. Bearings from nesting areas to the settlement regions were again significantly different from random (Rayleigh test: $z=6.19, n=19, p<0.01)$.

\section{Summering and wintering site fidelity}

Five out of nine birds that survived the first winter and could be tracked subsequently spent the following summer in the same area. The remaining four birds left the wintering area between the end of March and mid-April and spent the next summer in regions at least $20 \mathrm{~km}$ distant from wintering grounds. Four individuals for which the second winter site could be recorded, as well as two individuals for which even the third winter site is known, returned to the same place as initially, showing a high fidelity to wintering site.

Ten out of 11 individuals did not breed at the end of their first year of life. Only one female successfully reared a brood in the year following its birth year. The two birds that could still be followed at the age of 2 years and the only one that was still alive and tracked at the age of 3 years had not yet attempted to breed at these early ages. 

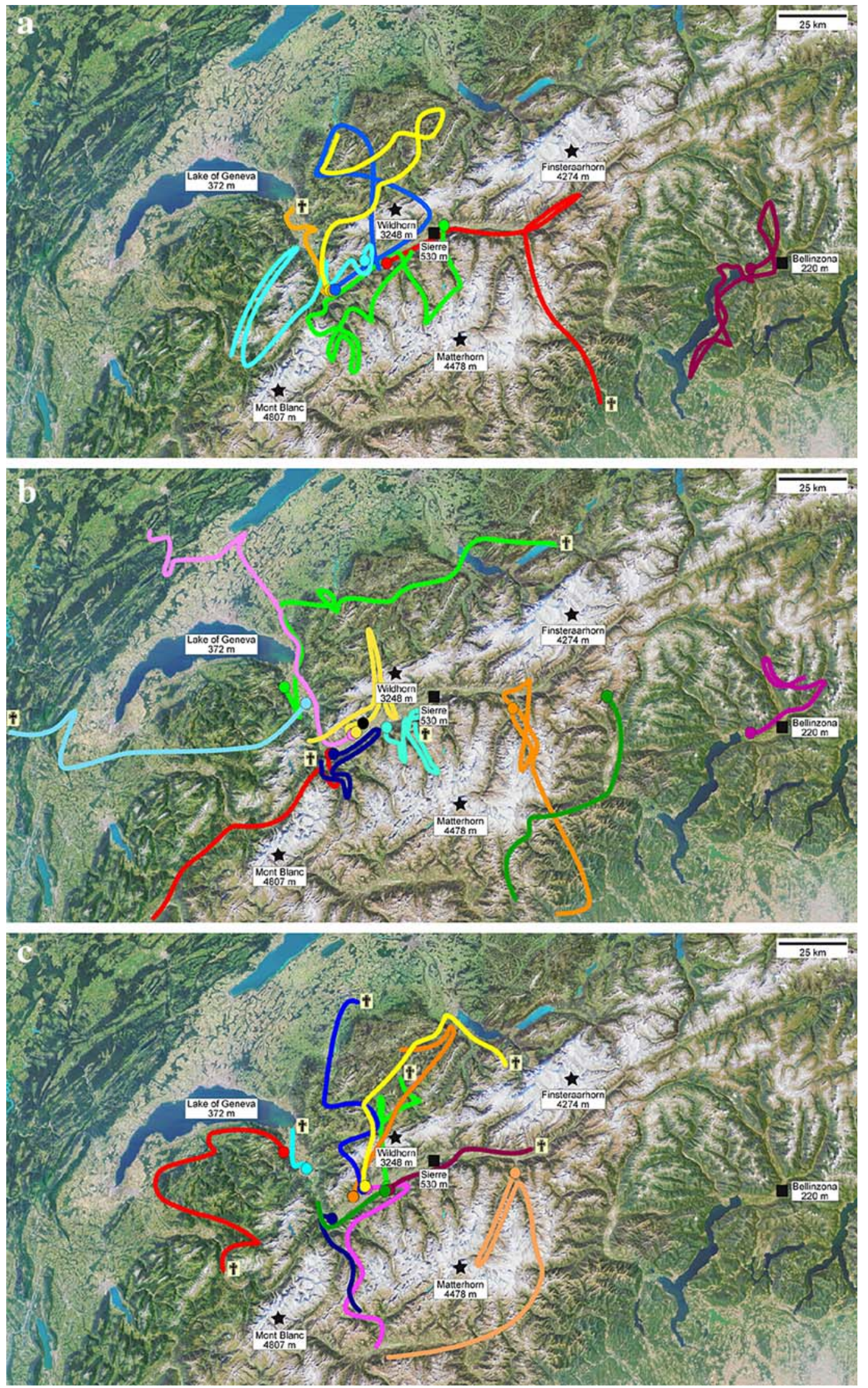
Fig. 3 Bearings from the nesting areas assessed after 2 days, 1 week, 2 weeks and at the end of the first phase of dispersal. Figures indicate the number of individuals in the respective direction
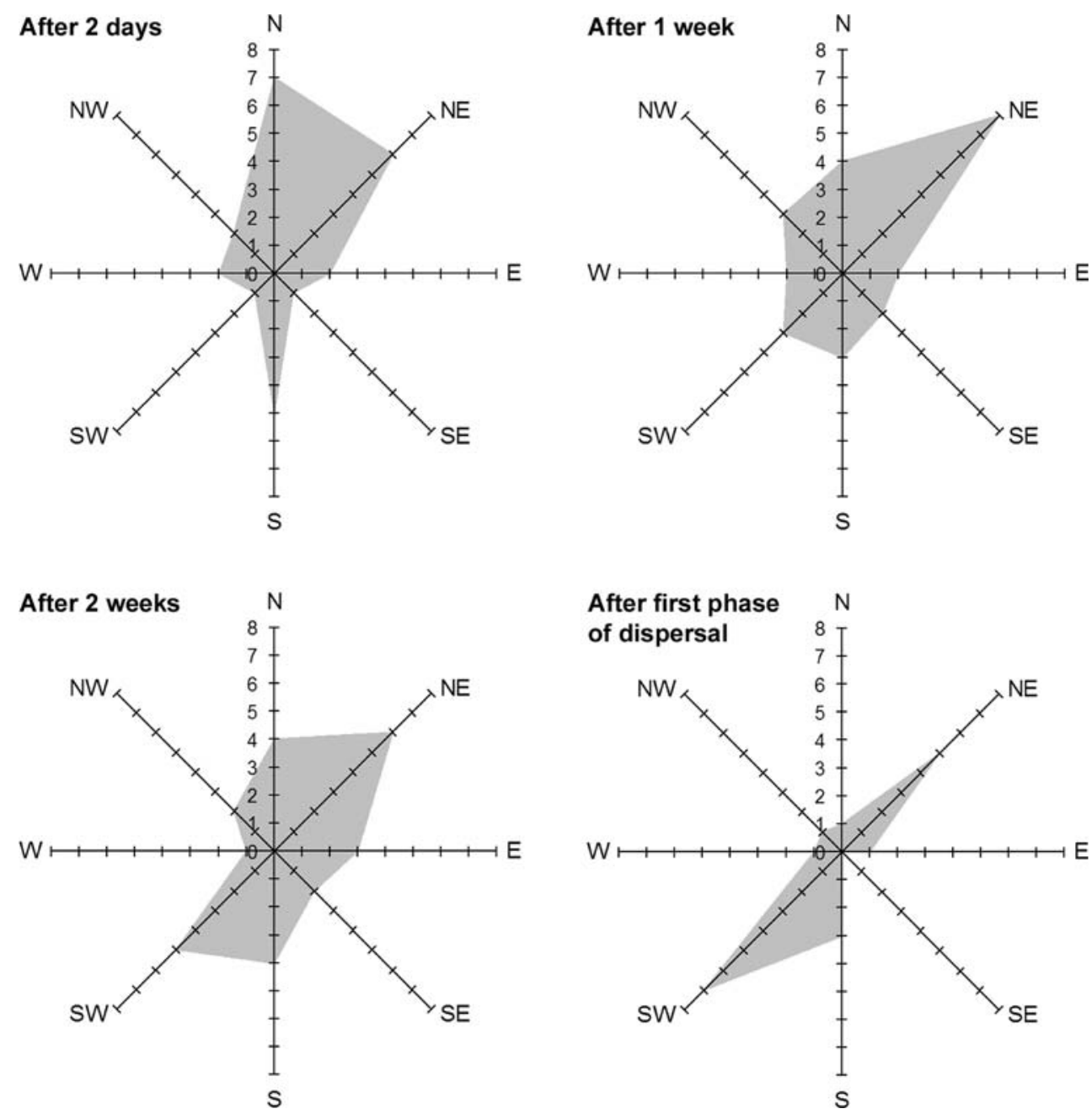

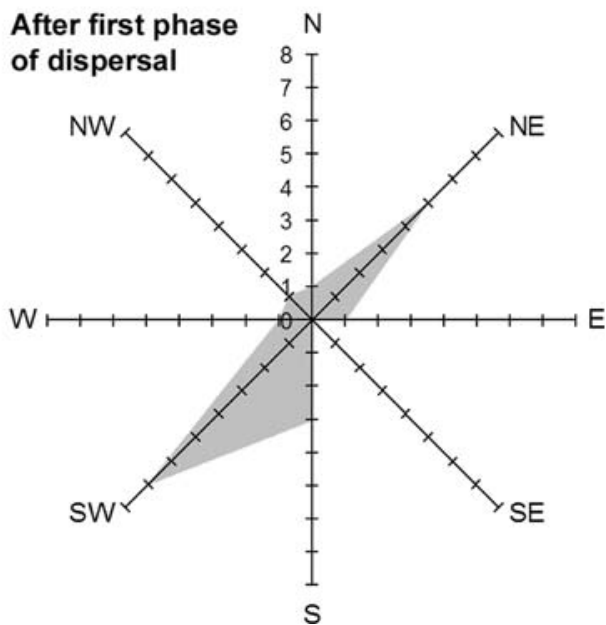

\section{Discussion}

The use of conventional and satellite radiotracking enabled us to collect inestimable data about pattern of juvenile dispersal in the Eagle Owl in the Alps. Contrary to young Eagle Owls in southwestern Spain that spent most of the post-fledging period before dispersing at distances farther than $500 \mathrm{~m}$ from the nest (Penteriani et al. 2005), our owlets spent this period in close vicinity to the nest. This can be explained by the fact that Eagle Owls in southwestern Spain are ground breeders, while all pairs in our study area are breeding on cliffs. Juvenile dispersal in our population is characterised by an initial nomadic phase, lasting on average 1 month, followed by a stay of several months in a new area. This latter zone usually then becomes the first wintering ground. This contrasts to the biphasic movement behavior described for dispersing Eagle Owls in Andalusia and does not comply with the late stop of the wandering phase of the Spanish birds at an average age of 1 year (Delgado and Penteriani 2008).
During dispersal in the complex terrain of the Alps, our young initially followed the principal valleys, upstream and downstream, but could, however, at any moment change movement directions and cross high altitude mountain passes. Even ridges at an altitude of up to 3,000 $\mathrm{m}$ a.s.l. were conquerable. Two-thirds of all individuals radiotagged in Valais left this deep valley, flanked by very high mountain ridges culminating at more than 4,000 m altitude, flying to Italy, France or to the northern slope of the Alps (cantons of Bern and Fribourg). This huge dispersal potential let us expect that similar immigration movements occur towards Valais from the adjacent areas in northern Italy and eastern France where breeding populations exist (Cochet 2006). In contrast, immigration from the north and the east is very unlikely as there are very few breeding pairs recorded there (Mosimann-Kampe et al. 1998; Schmid et al. 1998). Yet, these suspected population movements towards Valais have not so far been documented; there are currently no ringing or radiotracking programmes in these parts of Italy and France although an extension of the species' range has been established recently along the 
Rhône valley in France, which is the natural continuation of the Swiss Rhône valley to the south of the Lake of Geneva (Cochet 2006).

The area where young Eagle Owls first settled was, on average, $46 \mathrm{~km}$ from nest. Our results on settlement distances confirm previous ring recoveries. Olsson (1979) showed that $25 \%$ of the young ringed as nestlings in a Swedish population were later found more than $50 \mathrm{~km}$ from the nest $(n=53)$. In Southern Germany and Austria, 60\% of all Eagle Owls ringed as young were recovered in a radius of less than $50 \mathrm{~km}(n=221$; Fiedler 2005). Thirtysix wild-born Eagle Owls ringed at the eyries in Switzerland were recovered at an average distance of $36 \mathrm{~km}$ (archive of the Swiss Ornithological Institute), whereas in a highdensity radiotagged population in Andalusia the mean settlement distance was only $9.1 \mathrm{~km}(n=25$; Delgado and Penteriani 2005). The longest recorded distances so far covered by wild born, ring-marked Eagle Owls range between 105 and $416 \mathrm{~km}$ (Haftorn 1971; Rockenbauch 1978; Görner 1985; Olsson 1997; Saurola 2002; archive of the Swiss Ornithological Institute; this study). The dispersal distances in Eagle Owl are similar to the distances recorded in the related Great Horned Owl (Bubo virginianus) (Rohner 1997), but longer than in some other owl species such as Ural (Strix uralensis) or Tawny (Strix aluco) Owls (Mebs and Scherzinger 2000; Saurola and Francis 2004). Our study of the Alpine Eagle Owl confirms the capacity of young to colonise new breeding sites far away from birth place and suggests the existence of a wide-scale metapopulation system, with exchanges across distant populations.

While some individuals have already left their parents in August, others only start dispersing in November. The high variability among juveniles as regards both departure time and duration of the first dispersal phase confirms findings by Delgado and Penteriani (2005) in Spain. Only the use of marking methods that allow the tracking of birds continuously, e.g. conventional or satellite radiotracking, enables the discovery of the exact dates when juvenile dispersal starts and ends, as well as the precise itinerary, i.e. the recording of the complete pattern of juvenile dispersal. The 29 Eagle Owl young which dispersed in this study sojourned in at least 13 different valleys where, to our knowledge, no breeding pairs were present. This shows that casual findings of dead Eagle Owls or feathers by no means inform about breeding range. During dispersal, some young Eagle Owls can cover several hundreds kilometres before settling, visiting many different places, habitats and regions. Birds tend to return to the initial area as the average settlement distance $(46 \mathrm{~km})$ was shorter than the mean maximum dispersal distance $(58 \mathrm{~km})$.

Olsson (1997) and Scherzinger (1987) found no preferred direction in dispersing Eagle Owls. It is somewhat astonishing that in our study a majority of juveniles dispersed first to $\mathrm{N}$ or NE. We were expecting dispersal along the main Rhône valley, which is oriented SE-NW (Lower Valais), NE-SW (Central Valais) and E-W (Upper Valais) (Fig. 2). Altogether, birds were much more flexible than we thought with respect to topography. Actually, 29\% of all individuals started dispersal towards a topographic barrier and almost two-thirds of all birds crossed at least once ridges above 2,000 $\mathrm{m}$ a.s.l.

It has been suggested that most Eagle Owls start to breed at the age of 3 years or later (Glutz von Blotzheim and Bauer 1980; Radler 1991; Olsson 1997). Although neither the VHF tags nor the satellite transmitters used in this study lasted long enough to evaluate age at first reproduction (longevity of our tags was maximum 30 months), we had one individual female breeding successfully in her first year of life. The fact that none of the dispersing birds could be heard calling on wintering or summering grounds despite hundreds of hours of field observation also supports the hypothesis of delayed age of first reproduction in this species. Furthermore, besides the one bird that was breeding in its first year of life, all other birds seemed not to actively search for a breeding place, although all of them came several times across a priori suitable if not formerly occupied breeding cliffs.

Unfortunately, the longevity of our radiotags hampered the monitoring of our Eagle Owls beyond sexual maturity. Although radiotracking enabled us to collect good data on survival (Aebischer et al., in preparation) and juvenile dispersal (this study), we still ignore the fate of the adult segment of our population. Only the refinement of radiotracking techniques, namely longer lifespan of battery packs, will enable us to gather this crucial information.

The degree of conservation endangerment of many species depends directly on species-specific dispersal ability and strategy (Johst et al. 2002). Dispersal distances are likely to be indicative of the spatial scale at which metapopulation exchanges potentially take place (Nathan 2001). In general, the lack of data on dispersal distances is considered as a major problem for understanding bird metapopulation dynamics (Brawn and Robinson 1996). Here, we could show that a marked exchange of individuals exists between remote areas both within the Alps and with neighbouring areas up to a distance of several dozens if not hundreds of kilometres. These areas may be topographically very much separated from each other, with high mountain ridges apparently representing no serious obstacle to juvenile dispersal in this species. We conclude that wide-scale juvenile dispersal is an essential component of Eagle Owl population dynamics in the NW Alps. Actually, this spatial dimension should be accounted for in the development of any conservation policy. Isolated, local actions, even if well targeted towards the mitigation of the most detrimental risks and mortality factors, will only have 
a limited impact on the overall population dynamics at the metapopulation level. In the case of the Eagle Owl in the NW Alps, an international coordination between Switzerland, France and Italy for developing a sound conservation policy would be an absolute requisite.

\section{Zusammenfassung}

Weiträumige Jugenddispersion beim Uhu (Bubo bubo) durch die Alpen erfordert länderübergreifenden Schutzmassnahmen

Obwohl die Jugenddispersion im Leben eines Vogels eine bedeutende Komponente darstellt, wissen wir bei den meisten Arten nur sehr wenig darüber, wie sich dieser ökologische Prozess auf die Populationsdynamik auswirkt. Dieser Kenntnismangel beeinträchtigt das Abschätzen des Status einer Population und kann das Formulieren von effizienten Schutzmassnahmen erschweren. Der Uhu Bubo bubo ist in den Alpen eine gefährdete Vogelart. Viele Brutplätze wurden im frühen 20. Jahrhundert verlassen. Zwar fand später mancherorts eine Wiederbesiedlung statt, doch blieben viele Orte verwaist. Zudem sind viele Brutplätze in den Alpen, trotz des relativ hohen Fortpflanzungserfolgs auf Populationsniveau, nur unregelmäßig besetzt. Der langfristige Fortbestand der Alpenpopulation scheint keineswegs gesichert. Mit Hilfe von konventioneller und von Satelliten-Telemetrie haben wir das räumlich-zeitliche Dispersionsmuster von 41 jungen Uhus in den südwestlichen Schweizer Alpen untersucht. Ziel war vor allem das Ermitteln der Dispersionsdistanzen sowie der Orte und des Zeitpunkts der Ansiedlung. Die Jungvögel verließen ihre Eltern zwischen Mitte August und Mitte November. Sie legten pro Nacht durchschnittlich $12.7 \mathrm{~km}$ zurück (Entfernung zwischen zwei Tageseinständen) und überflogen dabei oft Bergketten und Pässe bis in Höhen über $3000 \mathrm{~m}$ ü.M. Die gesamte zurückgelegte Distanz betrug durchschnittlich $102 \mathrm{~km}$ (Summe der Nachtetappen), bei einem Maximum von $230 \mathrm{~km}$. Nach der Dispersion befanden sich die Vögel durchschnittlich $46 \mathrm{~km}$ vom Geburtsort entfernt. Unsere Studie zeigt, dass die Jugendispersion beim Uhu selbst im Gebirge regelmässig über große Entfernungen erfolgt, und weist auf eine großräumige Metapopulation in den Nordwestalpen hin. Dieser Individuenaustausch über weite Strecken muss bei Artenförderungsprogrammen berücksichtig werden.

Acknowledgments The present study was funded by grants from the MAVA Foundation for the Protection of Nature, by the Loterie Romande, by the Zürcher Tierschutz and by the Swiss Ornithological Institute. We also acknowledge the financial support of the Rita Roux foundation, the Museum of Natural History in Fribourg and the Cercle Ornithologique de Fribourg. Many thanks to S. Mettaz, P. Grand,
N. Jordan, J.-L. Abbet, F. Desmet, S. Koch, R. Lardelli, R. Bionda, G. Rochat, C. Grand and V. Dupuis for assistance in field work and for reporting their observations. We are grateful to B. Muffat-Joly and M. Arvin-Berod from the Office National de la Chasse et de la Faune Sauvage for the many field controls they made in Haute-Savoie. Thanks also to the gamekeepers from the cantons of Valais, Vaud and Bern for various forms of collaboration and to the Swiss Ornithological Institute that made available the ring recovery data from their archive. Finally, we thank V. Penteriani and L. Dalbeck for their valuable comments on the manuscript. Licences statement: this study has been carried out in full compliance with the Swiss legislation under licence from the Swiss Federal Office for the Environment and the cantonal Game and Fishery Services of Valais and Vaud, and following the guidelines for the use of free-ranging, wild animals in research.

\section{References}

Aebischer A, Nyffeler P, Koch S, Arlettaz R (2005) Jugenddispersion und Mortalität Schweizer Uhus Bubo bubo - Ein aktueller Zwischenbericht. Ornithol Anz 44:197-200

Arlettaz R (1988) Statut du hibou grand-duc, Bubo bubo, en Valais Central. Bull Murith 106:3-23

Batschelet E (1981) Circular statistics in biology. Academic, London

Bowler DE, Benton TG (2005) Causes and consequences of animal dispersal strategies: relating individual behaviour to spatial dynamics. Biol Rev Camb Philos Soc 80:205-225. doi:10.1017/ S1464793104006645

Brawn JD, Robinson SK (1996) Source-sink population dynamics may complicate the interpretation of long-term census data. Ecology 77:3-12. doi:10.2307/2265649

Breuer W (2007) Stromopfer und Vogelschutz an Energiefreileitungen. Bundesnaturschutzgesetz in der Praxis. Natursch Landsch 39:69-95

Breuer W, Brücher W, Dalbeck L (2009) Straßentod von Vögeln - Zur Frage der Erheblichkeit am Beispiel des Uhus. Natursch Landsch 41:41-46

Burnham KP (1993) A theory for combined analysis of ring recovery and recapture data. In: Lebreton JD, North PM (eds) Marked individuals in the study of bird population. Birkhäuser, Basel, pp 199-213

Clobert J, Danchin E, Dhondt A, Nichols JD (2001) Dispersal. Oxford University Press, Oxford

Cochet G (2006) Le grand-duc d'Europe. Delachaux et Niestlé, Paris

Defontaines P (2002) Suivi sur 20 ans d'une population de Grandsducs d'Europe Bubo bubo en Languedoc. Alauda 70:15-22

Delgado MM, Penteriani V (2005) Eagle owl Bubo bubo dispersal patterns and the importance of floaters for the stability of breeding populations. Ornithol Anz 44:153-158

Delgado MM, Penteriani V (2008) Behavioral states help translate dispersal movements into spatial distribution patterns of floaters. Am Nat 172:475-485. doi:10.1086/590964

Fiedler W (2005) Ist Uhuberingung noch zeitgemäß? Anforderungen an Uhu-Beringungsprogramme aus Sicht der Vogelwarte. Ornithol Anz 44:171-176

Glutz von Blotzheim UN, Bauer K (1980) Handbuch der Vögel Mitteleuropas, vol. 9. Akademische, Wiesbaden

Görner M (1985) Aktuelle Probleme des Uhuschutzes (Bubo bubo) in Thüringen. Veröf Mus Gera. Naturwiss R 11:70-73

Haftorn S (1971) Norges Fugler. Universitetsforlaget, Oslo

Hays GC, Akesson S, Godley BJ, Luschi P, Santidrian P (2001) The implications of location accuracy for the interpretation of satellite-tracking data. Anim Behav 61:1035-1040. doi:10.1006/ anbe. 2001.1685 
Johst K, Brandl R, Eber S (2002) Metapopulation persistence in dynamic landscapes: the role of dispersal distance. Oikos 98:263-270. doi:10.1034/j.1600-0706.2002.980208.x

Marchesi L, Sergio F, Pedrini P (2002) Costs and benefits of breeding in human-altered landscapes for the eagle owl Bubo bubo. Ibis 144:164-177. doi:10.1046/j.1474-919X.2002.t01-200094_2.x

Mebs T, Scherzinger W (2000) Die Eulen Europas. Franckh-Kosmos, Stuttgart

Mosimann-Kampe P, Haller H, Arlettaz R (1998) Verbreitung und Bestand des Uhus Bubo bubo in der Schweiz. Ornithol Beob 95:143-151

Nathan R (2001) The challenges of studying dispersal. Trends Ecol Evol 16:481-483. doi:10.1016/S0169-5347(01)02272-8

Olsson V (1979) Studies on a population of eagle owls Bubo bubo (L.) in southeast Sweden. Viltrevy (Stockh) 11:1-93

Olsson V (1997) Breeding success, dispersal, and long-term changes in a population of eagle owls Bubo bubo in southeastern Sweden 1952-1996. Ornis Svec 7:49-60

Penteriani V, Delgado MM, Maggio C, Aradis A, Sergio F (2005) Development of chicks and predispersal behaviour of young eagle owls Bubo bubo. Ibis 147:155-168. doi:10.1111/j.1474919x.2004.00381.x

Penteriani V, Otalora F, Ferrer M (2006) Floater dynamics can explain positive patterns of density-dependent fecundity in animal populations. Am Nat 168:697-703. doi:10.1086/507995

Radler K (1991) Populationsbiologische Untersuchungen zum Artenschutz beim Uhu (Bubo bubo). Gott Forstgen Ber 11:1-112

Rockenbauch D (1978) Untergang und Wiederkehr des Uhus Bubo bubo in Baden-Württemberg. Anz Orn Ges Bayern 17:293-328

Rohner C (1997) Non-territorial floaters in great horned owls (Bubo virginianus). In: Duncan JR, Johnson DH, Nicholls TH (eds)
Biology and conservation of owls of the northern hemisphere. US Department of Agriculture, Forest Service, St. Paul MI, pp 347-362

Rubolini D, Bassi E, Bogliani G, Galeotti P, Garavaglia R (2001) Eagle owl Bubo bubo and power lines interactions in the Italian Alps. Bird Conserv Int 11:319-324. doi:10.1017/ S0959270901000363

Saurola P (2002) Natal dispersal distances of Finnish owls: results from ringing. In: Newton I, Kavanagh R, Olsen J, Taylor I (eds) Ecology and conservation of owls. CSIRO, Collingwood, pp 42-55

Saurola P Francis CM (2004) Estimating populationdynamics and dispersal distances of owls from nationally coordinated ringing data in Finland. AnimBiodivers Conserv 27:403-415

Scherzinger W (1974) Die Jugendentwicklung des Uhus (Bubo bubo) mit Vergleichen zu der von Schneeule (Nyctea scandiaca) und Sumpfohreule (Asio flammeus). Bonn Zool Beitr 25:123-147

Scherzinger W (1987) Der Uhu Bubo bubo im Inneren Bayerischen Wald. Anz Orn Ges Bayern 26:1-51

Schmid H, Luder R, Naef-Daenzer B, Graf R, Zbinden N (1998) Schweizer Brutvogelatlas. Schweizerische Vogelwarte Sempach, Sempach

Sergio F, Marchesi L, Pedrini P, Ferrer M, Penteriani V (2004) Electrocution alters the distribution and density of a top predator. J Appl Ecol 41:836-845. doi:10.1111/j.0021-8901.2004.00946.x

Valkama J, Saurola P (2005) Mortality factors and population trends of eagle owls Bubo bubo in Finland. Ornithol Anz 44:81-90

Vincent C, McConnell BJ, Ridoux V, Fedak MA (2002) Assessment of Argos location accuracy from satellite tags deployed on captive gray seals. Mar Mamm Sci 18:156-166. doi:10.1111/ j.1748-7692.2002.tb01025.x 